
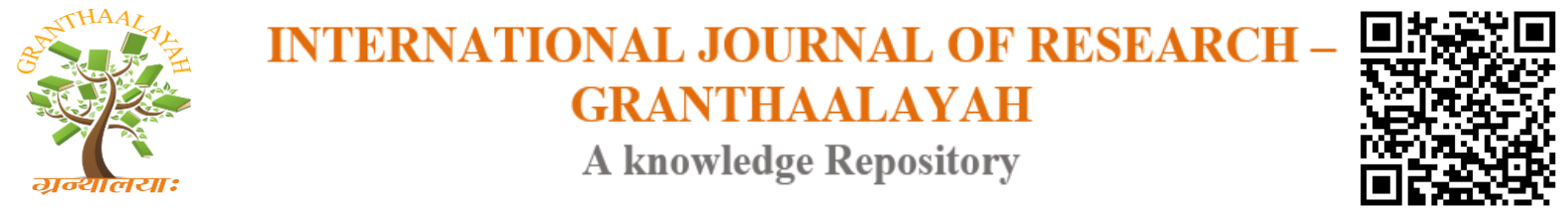

Science

\title{
IMPACT OF INFORMATION COMMUNICATION TECHNOLOGY ON LIBRARY AND ITS SERVICES
}

\author{
Dr. Javed Khan *1 \\ ${ }^{* 1}$ Assistant Professor, Swami Vivekanand Subharti University, Meerut, INDIA
}

DOI: https://doi.org/10.29121/granthaalayah.v4.i9.2016.2540

\section{ABSTRACT}

Computing technology, communication technology, and mass storage technology are some of the areas of continuous development that reshape the way libraries access, retrieve, store, manipulate, and disseminate information to users. ICT has impacted on every sphere of academic library activity especially in the form of the library collection development strategies, library building and consortia. Information and Communication Technology (ICT) has brought unprecedented changes and transformation to academic library and information services, conventional LIS such as OPAC, user services, reference service, bibliographic services, current awareness services, document delivery, interlibrary loan, audio visual services, and customer relations can be provided more efficiently and effectively using ICT, as they offer convenient time, place, cost effectiveness, faster and most-up-to-date dissemination and end users involvement in the library and information services process. The impact of ICT characterized on information services by changes in format, content and method of production, and delivery of information products. Emergence of the Internet as the largest repository of information and knowledge, changed role of library and information science professionals from intermediary to facilitator, new tools for dissemination of information and shift from physical to virtual services environment and extinction of some conventional information services and emergence of new and innovation web based.

Keywords:

Library, Information Communication Technology, ICT.

Cite This Article: Dr. Javed Khan, "IMPACT OF INFORMATION COMMUNICATION TECHNOLOGY ON LIBRARY AND ITS SERVICES" International Journal of Research Granthaalayah, Vol. 4, No. 9 (2016): 97-100.

\section{INTRODUCTION}

Information and Communication Technology (ICT) has transformed library services globally. Most current information are recorded in electronic format, ICT has also contributed immensely to the performance of librarians in the discharge of their duties such as in cataloguing, reference 
services, circulation management, serials control etc. ICT has contributed to the library in the following specific ways.

\section{CONCEPT OF INFORMATION COMMUNICATION TECHNOLOGY (ICT)}

The term Information and Communication Technology (ICT) is more commonly used. Whilst Information Technology (IT) has been the accepted term in the UK and USA, it is not the universal term. Telemetric is widely used in France, and Information is also used elsewhere in this sense. ICT deals with the use of electronic computer and computer software to convert, store, protect, process, transmit, and retrieve information.

\section{NEEEDS OF INFORMATION TECHNOLOGY}

Due to information explosion it is very difficult to handle large information with traditional library tools like manual catalogue, bibliographies, etc. In today's library environment, to provide the right way, is not possible without ICT application. ICT has become necessity and need.

\section{IMPACT OF INFORMATION COMMUNICATION TECHNOLOGY}

In old days library was considered as mere storehouse of knowledge. But these days ICT has reshaped the functioning and services of libraries. The activities which were carried out manually are being carried out effectively and smoothly with the help of ICT. ICT has changed the way of acquisition, technical processing, periodical subscription, and circulation activities etc. in such a way that library readers can get desired information and services effectively in shortest time with less man power involvement. This is the information age because information technology is growing fast. Traditional libraries are changing their role and functions according to the new trends in the society. Library is providing information through the computers and internet. It can be said that without the help of the computers and internet any library information Centre cannot satisfy the users.

\section{NECESSITY FOR ICT IN LIBRARIES}

To speed-up accurate and reliable data transfer in future there is also a danger of non-availability of hard copies of documents, particularly to secondary sources that are available only on CDROM. Knowing this, continuing education about ICT for libraries is essential. Due to the escalation in prices of periodicals and books, no library can afford to acquire all the publications; resource sharing through networking is the only option. To participate in the network, computerization of libraries is a prerequisite. Many International databases like DIALOG, MEDLARS, INIS, AGRIS, etc. are delivering the information electronically. Unless the libraries are automated, there is no possibility for accessing the information from these global level databases.

The literature in almost all the fields is increasing tremendously and in a multidimensional way. Because of this growth, manual bibliographic control is not feasible and ICT is needed. The information seeking behaviour of the users is also changing according to their varied needs. To 
meet these hanging needs, storage capacities of information and retrieval techniques should be improved. The quality, user friendless, effectiveness, reliability and regularity of library services can be much improved through ICT.

1) To utilize the growing world of electronic information, application of ICT is necessary.

2) With the help of ICT it is possible to gain local, national, regional and international reputation.

3) To be able to provide round the clock access and service to users.

4) To access experienced and expert individuals in my fields;

5) To provide regular updates on topics of interest to users;

6) To promote teamwork across geographical distance;

\section{ICT-BASED USER SERVICES}

Some library users are adopting electronic habits, making increasing use of the new ICT including computers, the Internet, the Web, Intranet, Extranet and other technologies. As a result, library users are placing new demands on their libraries. They require access to the latest information, updated information resources and access to ICT facilities that they could use in their work.

Use of ICT in libraries enhances user's satisfaction. It provides numerous benefits to library users. Some of the benefits are:

- Provide speedy and easy access to information

- Provides remote access to users

- Provides round the clock access to users

- Provides access to unlimited information from different sources

- Provides information flexibility to be used by any individual according to his/her requirements

- Provides increased flexibility

- Facilitates the reformatting and combining of data from different sources

Libraries are also providing various ICT-based services to their user, including the following Provision of Web access to OPACs

- Electronic document delivery

- Networked information resources

- Delivery of information to user desktops

- Online instructions

- Online readers advisory services

\section{ADVANTAGES OF USING ICT IN THE LIBRARY}

- ICT makes library work easier, faster, cheaper and more effective.

- Helps to manage information overload as information retrieval is made easier in computerized systems.

- Remote access is enabled through networked systems. 
- Computerization saves space and reduces paper.

\section{CHALLENGES OF USING ICT IN LIBRARIES}

- Poor funding of ICT infrastructures

- Constant change of software and hardware

- Erratic power supply

- Insufficient bandwidth

- Lack of technical IT knowledge by library staff

- Copyright and intellectual property rights management

\section{CONCLUSION}

In fact, it is now difficult to imagine a world without information technology. The provision and use of ICT is part and parcel of the entire system, to both the students, information professionals and the institutions. With the help of ICT to deliver the services of their user is very easy and fast and also it can save the time of user and staff both. Nowadays ICT has totally changed the concept of library and information center as it was in early days. Libraries are adopting ICT for performing both housekeeping operations as well as for providing services to the library patrons. Application of ICT has added value to the services and libraries are becoming popular among the patrons. With the aid of ICT libraries are actually marching towards achieving the goal of providing pinpointed exhaustive and expeditious information to those who are in need of that information. Information and communication technology is applied for providing information services which are more convenient, better accessible and cost effective.

\section{REFERENCES}

[1] Vinitha, K Kanthimathi (2006) "Impact of Information and Communication Technology on Library and its Services" ICT Conference on Digital Learning Environment 11-13 Jan. 2006 Bangalore.

[2] Patra, B.K (2008) "The Role of Information and Communication Technology on Management and Services of Academic Libraries. Technology India Group Research Journal, 1 (1).

[3] Haneef Mohamed (2009) "Application of Information and Communication Technologies in Special Libraries in Kerala (India), Library Review, Vol. 56; 7, pp. 603-620.

[4] Kumar Sampath (2010) "Use of ICT in College Libraries in Karnataka, India: A Survey" Program: Electronic Library and Information Systems 44 (3): 271-282.

[5] Parasher, R.G "Information and its Communication" New Delhi: Medallion, 1991. 